\title{
Pedagogical conditions for the development of students in industrial practice
}

\author{
${\text { Uygun } \text { Urinov }^{1 *} \text { and Sevara Adizova }}^{1}$ \\ ${ }^{1}$ Bukhara Engineering-Technological Institute, 200100, Bukhara region, Bukhara city, 15, \\ K.Murtazoev str., Republic of Uzbekistan
}

\begin{abstract}
The article covers the tasks of developing practical skills of the students through cooperation between higher education institutions and manufacturing enterprises. It has been stated that practical skills are mainly formed by consolidating the acquired theoretical knowledge in the process of internship in production. There are shown purposes and processes which lead to achieve them. It has been emphasized that professional activity in students is formed by completing tasks that require complex skills. There are some recommendations for organizing and holding internship at a stand. This article is defined experimental works on progressing professional capacity in process of practical training. The changes in the evaluation process at the final stage of the production internship and the levels of mastery introduced are discussed. According to the students, the internship process in the production has intensively increased their professional and practical skills. It is stated that during the internship, students were divided into two groups and experimental work was carried out in these two groups. It is also stated that the theoretical knowledge acquired by students is intended to develop practical skills through practical training. During the internship the groups were divided into a control group and an experimental group. It is stated that the internship was organized among the students. It was noted that the practical training of students in the control groups was traditionally organized, and the internship of the experimental groups was improved.
\end{abstract}

\section{Introduction}

The training of students in accordance with the requirements of labor market through cooperation between the higher education system and industrial enterprises is one of the main requirements in higher education. This is expressed in the Decree of President of Republic of Uzbekistan No. PP-2909 dated April 20, 2017 "About measures for further development of system of the higher education". The Decree was issued in order to radically reconsider the content of training in accordance with the priorities of social and economic development of the country, to create the necessary conditions for the training of specialists with higher education at the level of international standards [1].

\footnotetext{
* Corresponding author: uygun21@mail.ru
} 
Internship process in production enterprises has a great contribution to the training of students at the level of qualified specialists in higher education. Industrial internship has been confirmed through several normative documents in the higher education system.

Industrial internship involves the improvement of practical skills in the subjects studied, the examination of students' skills in the application of theoretical knowledge in internship, the acquisition of professional skills and abilities. In particular, it is aimed at strengthening the theoretical knowledge acquired by students in the educational process and the transformation of this knowledge into skills and abilities of future professional activity, preparing students for practical work in a specific workplace.

Part of the training activities of future specialists consists of pedagogical, educational and industrial internship. It is necessary for further developing the relationship between the higher education institution and the enterprise or organization in order to monitor the activities of students in the application of knowledge acquired in higher education and to ensure transparency and objectivity in the evaluation of these activities. This is because future professionals will have the opportunity to consolidate and apply the knowledge they have acquired during their internship.

\section{Materials and methods}

Industrial professional internship of students is important component of the main educational program of higher education. Its purpose is to consolidate and deepen the knowledge gained by students in the process of theoretical training, to acquire the necessary skills, abilities and practical experience in the studied specialty.

Internship is specifically agency, conscious, aim-setting, sensory-objective, material activity. Any internship is characterized as a unity of the objective (prerequisites, means and result) and subjective (the specific activity of a person who uses his intellectual abilities, thinking, knowledge and practical experience).

For the successful industrial internship of students-future engineers at enterprises, the educational institution provides preliminary theoretical and professional training for students in training workshops, at training grounds in accordance with curricula and programs. During the educational process students must first study the rules and requirements for the technical and safe operation of machines, the rules of safe activity in the workplace, the rules of industrial sanitation, fire safety rules and labor protection rules provided for the relevant professions

The educational institution in cooperation with manufacturing enterprises determine in advance the objects of industrial internship, agree on the timing of their implementation, draw up schedules for the movement of students to workplaces in such a way that each trainee has the opportunity to learn to independently perform all the work stipulated by the curriculum of industrial internship and the corresponding characteristic of wage-rate schedule of jobs and professions.

Industrial internship of the students has the following purposes: "consolidation of theoretical knowledge and acquisition of skills; mastering technological processes, equipment elements, laboratory testing methods; familiarization with the materials and documents of the functioning of production divisions" [2]. The educational institution is obliged to provide: referral of students to the enterprises within the terms established by the curricula, programs, contract and agreed with the organization (enterprise); full use for its intended purpose of the volume of hours allotted by the curriculum for industrial internship of students; study and observance by trainees of the internal labor regulations, safety, labor, fire safety, sanitary and hygienic requirements, safety instructions and other norms and rules established for the relevant professions and qualifications of workers of the organization (enterprise); compliance by students with the established requirements for the operation of 
equipment, machines, tools, the correct use of the personal protective equipment issued to them, as well as the economical use of materials and electricity by students [3].

\section{Results}

In our view, professional activity consists of performing occupational functions that require complex skills. Most of them are cross-subject skills. So, for example, for a student of a future engineer to work in production practice to complete a typical production task "Manufacturing a part", it is necessary to make all calculations and accounts, develop a description of the technological process for one part. The specificity of the work is such that each student must individually perform all the necessary calculations in a workbook in succession.

One of the main tasks is to optimize the network of educational institutions in order to bring its result of graduates closer to the requirements of the labor market. Educational process must being closed to production activities for making students competitive. In this regard, it is advisable to provide a complex of pedagogical conditions recommended by scientists for the formation of professionally significant qualities [4].

We highlight following among the recommendations:

Modern material and technical support of conditions for internship. For this purpose, a careful selection of internship bases, the conclusion of contracts, the identification and selection of objects in the research area, the development of internship plan, and familiarization with the personnel are necessary.

Scientific and methodological work with pedagogical personnel and supervisors of industrial training. In addition to internal scientific and methodological work, it is advisable to organize the participation of teachers and masters of industrial training in scientific and practical conferences of regional universities, problem seminars, and meetings with partners, regional and state competitions for highly qualified specialists.

Organization of psychological and pedagogical support. This condition is important not only at the first stage of industrial internship, but also at the stages of specialization and in research work. Personal guardianship and mentoring is the most productive.

The use of various means, forms and methods for the implementation of educational forecasting of possible professional actions, depending on the goals and objectives. Selfassessment and mutual assessment, self-analysis and mutual analysis of professional actions performed by fellow students. Performing independent or group research work. Execution of competitive tasks. Use of non-traditional forms of control.

Change of emphasis in the classroom and in industrial internship towards innovation in production. Developing industrial internship "in a spiral" from introductory to specialized professional and creative individual. Deductive learning the content of academic disciplines at certain stages of theoretical training and the use of adaptation tasks are associated with the needs for prompt creative change in the content of the lesson.

Using active teaching methods, e.g. business games, apply solutions to discussions, simulating incipient problems of professional activity situation.

Success of the process of forming the professional competence of a future specialist will be facilitated by the harmonization of the impact of external and internal conditions, which can be best ensured in a specially organized industrial internship. Based on this provision, we determined the production internship as a system-forming factor in the formation of the professional competence of the future technician, in which individualized process of mastering professional experience, professional knowledge, professional skills and abilities are carried out in the course of solving increasingly complex technical problems using innovative equipment. In addition to the aforementioned invariant characteristics of industrial internship, variable requirements were made: ensuring the successful implementation of personal professional social and moral choice, updating the cognitive, activity and 
motivational-value spheres of the individual and building an individual system of professional value relationships.

The processes of interaction between educational institutions and production, carried out in market conditions, are influenced by a set of economic, social, legal, technological, and personal factors that are consequences of the uncertainty of the modern social environment. However, for all the unexpectedness of their occurrence and the destabilizing nature of their influence, they, at the same time, contribute to the identification of potential reserves and trends in the development of interaction in the "educational institution - enterprise" system, which, in turn, determine the nature and dynamics of changes in the process of training future specialists for work in new conditions.

As a result of a combination of these factors, firstly, the production technological conditions are transformed; secondly, the requirements of the employer for the professional competence of the future specialist are specified; thirdly, the relationship in the "educational institution - enterprise" system is being updated and strengthened; fourth, the educational methodological support of the process of forming professional competence in industrial internship is being improved [5].

\section{Discussion}

We experimented with teaching methods at Tashkent State Technical University, Navoi State Mining Institute, Fergana Polytechnic Institute, Namangan Engineering and Construction Institute. 95 holders of "5320200 - Mechanical engineering technology, equipment and automation of mechanical engineering" bachelor's degree students were in control groups, and 102 students participated in experimental groups.

We approached to send students to industrial internship in places of their possible employment. The industrial internship of students - future engineer was organized based on the leading enterprises of the industry. When choosing places for internship, preference is given to those enterprises, institutions and organizations that have modern equipment.

During their internship, teachers closely interact with employees of enterprises on the development and correction of requirements for training in the workplace, for the development of materials and training methods. At the same time, trainers and managers of the internship have the opportunity to improve their knowledge of modern production processes as part of internships at enterprises.

In recent years, because the training of specialists began to be determined not by the needs of the industry as a whole, but by the development priorities of each region, the issue of employment of graduates has become especially urgent. Their job assurance is an important indicator of the competitiveness of an educational institution. The close relationship of the educational institution with enterprises employers allows training young specialists adapted to modern working conditions. Cooperation of students and staff of basic enterprises during internship allows the former reasonably approach the choice of work and the latter to the choice of future employees. Because of such joint activities, awareness of the mutual necessity is growing: the educational institution needs enterprises as its customers, capable of communicating new qualitative requirements for graduates, and enterprises increasingly consider the educational institution as a source of modern qualified personnel.

Improving training at the enterprise during industrial internship is an integral part of the entire process of training and education. Future engineers get the opportunity to acquire skills in their profession and prepare themselves for future work activities. During internship, they find themselves under the most direct influence of the team, of which they will become members at the end of the university. The way of how the relationship between interns and cadres develops, how future graduates will enter the team and how the team will accept them will largely determine their entire further career. The effectiveness of industrial internship 
largely depends on its organization, on what positive impact the labor collective will have on the process of training a young technician.

Based on the analysis of the theoretical base of the research and taking into account the results of generalization of the practical experience of teachers and masters of industrial training, we made the conclusion that industrial internship is a factor in the formation of professional competence of students. This gave us the basis to clarify the formulation of the concept of "industrial internship". In our opinion, industrial internship is a factor in the formation of students' professional competence and characterized by a certain content (a set of pedagogical and industrial conditions that ensure the implementation of developmental differentiation in organizing the experience of successful independent production activity of students) and structural (cognitive, motivational value, activity blocks in a holistic unity and relationship) by the organization. Industrial internship determines the procedural aspect of the achievement demanded by the individual, society and production of the level of professional competence of specialists.

Institute, together with the basic enterprises where students undergo practical training, successfully solve complex problems of training qualified specialists. In production internship, a lot of preparatory work is preceded: the conclusion of contracts with enterprises, the selection of jobs, and the execution of contracts with mentors. Managers of industrial internship should treat with great responsibility the control over the passage of students' internship at the enterprise. It is necessary to reach every student in order to see with his own eyes the successes and shortcomings of organizing and conducting internship, to be acquainted with how trainees acquire independence and adapt to working conditions at the enterprise. In production internship, it is necessary to create conditions for students to feel truly involved in the enterprise, completing assigned tasks on their own, mastering several operations and working on many types of equipment. It is necessary to create conditions for each trainee to show what he is capable of, what he has learned.

Professionally trained graduates, having proven themselves on a good side in internship, are willingly invited to work. We provide students with free attendance of classes if they combine study and work. This allows graduates to take a more responsible attitude to the development of knowledge, to acquire production skills.

Industrial internship takes $60 \%$ of the entire study time and is the main component of professional training, and the quality of its organization largely depends on whether a graduate succeeds as a specialist in order to become a full-fledged worker when he comes to production. Today, the organization of industrial internship in secondary specialized educational institutions lags behind the requirements of our time. At the same time, there is no personal significant social problem. It is necessary to search for new ways in the rapidly changing social and economic realities, it is necessary to transform industrial internship into a pedagogically controlled process [11].

Experimental work on the development of professional competence of students in the process of industrial internship was carried out [12].

The industrial internship pursued the achievement of two groups of goals: cognitive, informative and educational goals (consolidation of knowledge gained in the process of theoretical training) and a socially oriented goals (gaining experience in establishing and developing contacts, business communication, interaction in group or collective cooperation, information exchange). Based on these goals, the method of organizing the internship of students was tested, focused on the development of professional competence by choosing basic enterprises equipped with modern equipment.

In the control groups, the organization of practical internship of students did not differ from the traditional one and was focused on the "application and consolidation of knowledge" received by students in the process of theoretical training. 
In the experimental groups, the principle of organization was its personality-oriented approach, providing an individual trajectory for the development of professional competence of young people.

Table 1. Results of experiments carried out in educational institutions.

\begin{tabular}{|c|c|c|c|c|}
\hline \multirow{2}{*}{$\begin{array}{c}\text { Mastery level of } \\
\text { students }\end{array}$} & \multicolumn{2}{|c|}{ In the experimental group $\mathrm{m}=196$} & \multicolumn{2}{|c|}{$\begin{array}{c}\text { In the control group } \\
\mathrm{n}=202\end{array}$} \\
\cline { 2 - 6 } & $\begin{array}{c}\text { At the beginning } \\
\text { of the } \\
\text { experiment }\end{array}$ & $\begin{array}{c}\text { At the end of } \\
\text { the experiment }\end{array}$ & $\begin{array}{c}\text { At the } \\
\text { beginning of the } \\
\text { experiment }\end{array}$ & $\begin{array}{c}\text { At the end of } \\
\text { the experiment }\end{array}$ \\
\hline Excellent & $29(15 \%)$ & $76(39 \%)$ & $20 \quad(10 \%)$ & $28 \quad(14 \%)$ \\
\hline Good & $47(24 \%)$ & $76(39 \%)$ & $55 \quad(27 \%)$ & $63 \quad(31 \%)$ \\
\hline Satisfactorily & $100(51 \%)$ & $44(22 \%)$ & $107(53 \%)$ & $105(52 \%)$ \\
\hline Unsatisfactory & $20(10 \%)$ & & $20(10 \%)$ & $6 \quad(3 \%)$ \\
\hline
\end{tabular}

Students received individual assignments aimed at expanding their professional skills, mastering production operations, performing various professional roles, and more. The place of internship was determined taking into account the personal orientation of the students, the requirement of the program and the modern equipment of enterprises, as well as modern way of organizing work.

As a result of our study, at the end of the experimental work in all educational institutions, the level of development of practical skills of students in the experimental group was 1.16 times higher than in the control group. The diagram view of these results is as follows:

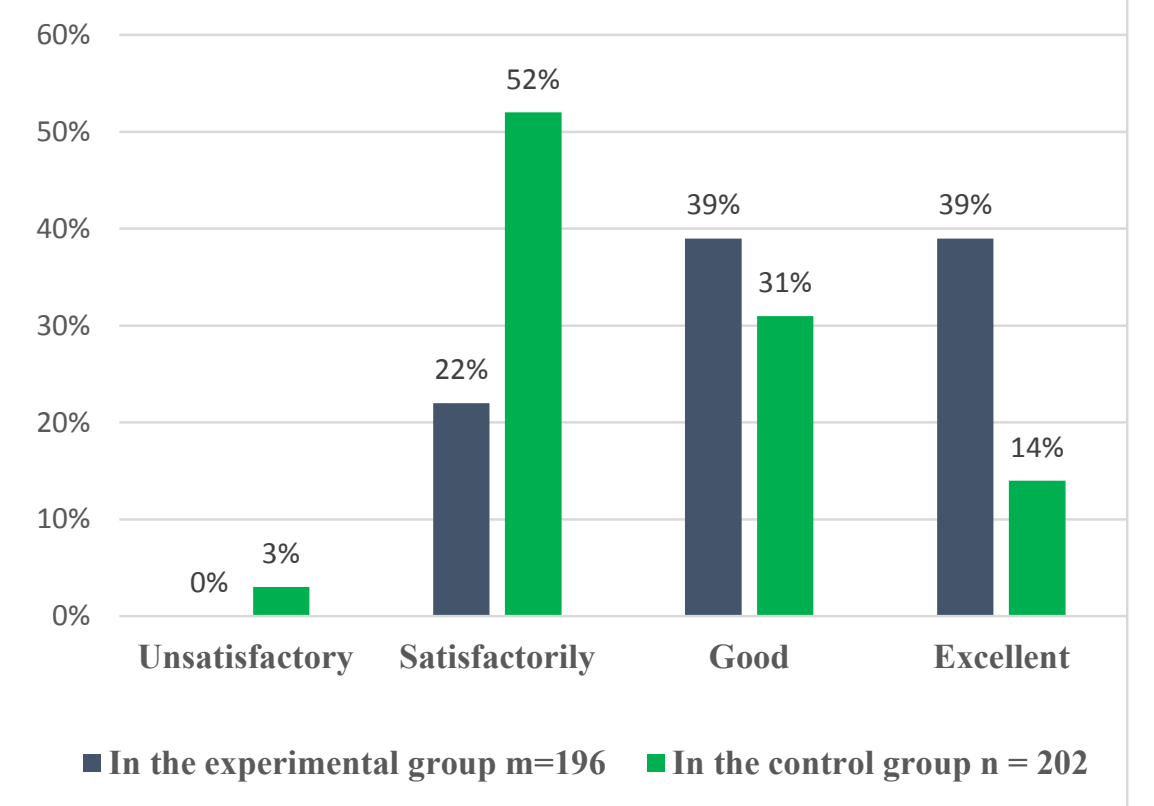

Fig. 1. Shows the progress of students in the control and experimental groups.

The involvement of students in real production processes was ensured by close ties between the institute and the managers of the internship with enterprises. 


\section{Conclusions}

We set followings as a conclusion of this research: we have changed the attitude to assessing the results of industrial internship: we lead in diagnostics development of professional competence of trainees, in particular, an assessment level the of mastering production operations and mastering communication skills, which are based on test results, observation of officials, analysis content of reports.

The observations were carried out in order to determine qualitative characteristics such as fluency in production operations, the ability to independently choose tools and methods of action, the ability to establish contacts, interact in business and personal communication, and develop a single strategy of action. Such personality traits are difficult to quantify, therefore in the experiment were indicated only positive or negative dynamics. Managers of internship noted the desire for independent work and the development of initiative in the implementation of common affairs in almost of all students. Especially, in their opinion, professional skills were improved intensively.

Revelation of the conditions for the development of professional competence of students - future technicians in industrial internship has now acquired particular relevance because of the aggravated social changes associated with the increased flow of information needed by specialists in various fields of activity and the rapid obsolescence of equipment at industrial enterprises.

In order to asses theoretical and practical knowledge of students according to practical training Various tests, questionnaires and task were made. Assessment criteria have been developed To estimate students knowledge and practical skills. The results of experimental works indicate that teaching by devising methods increased the level of excellent" and "good marks and decreased unsatisfactory and satisfactory grades in the control groups.

Mathematical statistical analysis of the experimental results showed that the status of the experimental and control groups differed from each other.

\section{References}

1. Resolution of the President of the Republic of Uzbekistan no. PQ-2909 "On measures to further develop the system of higher education", http://www.lex.uz (accessed April. 20, 2017).

2. S.Yu. Adizova, International Journal of Advanced Science and Technology, 29, 8, 3167-3172 (2020)

3. S.Yu. Adizova, Scientific reports of Bukhara state university 83, 251-261 (2021)

4. U.Sh. Begimkulov, Informatization of pedagogical education: theory and internship (Monography, Tashkent. Fan, 2011)

5. S.S. Hikmatovna, R. Shuxrataxadovich, Annals of the Romanian Society for Cell Biology 25(2), 2946-2949 (2021)

6. I.U. Muradilloyevich, O.K. Tanzilovch, A.A. Anvarovich, S.I. Baxodirovna, Journal of Critical Reviews, 7(14), 81-88 (2020) doi:10.31838/jcr.07.14.12

7. F.R. Muradova, Virtual laboratories in teaching and education. ISJ Theoretical \& Applied science (Philadelphia, USA, 2020)

8. B.S. Nuridinov, U.A. Urinov, Journal of vocational education, 6, 1, 11-16 (2003)

9. K.T. Olimov, International Journal of Innovative Technology and Exploring Engineering 9, 425-429 (2019)

10. B.G. Rashidovich, A.S. Abdurakhmanovich, A.A. Anvarovich, Journal of Critical Reviews, 7(14), 72-74 (2020) doi:10.31838/jcr.07.14.10 
11. U.A. Urinov, European Journal of Research and Reflection in Educational Sciences.

Great Britain. Progressive Academic Publishing, 8, 2, 62-65 (2020)

12. U.A. Urinov, ACADEMICIA: An International Multidisciplinary Research Journal, 10, 10, 1321-1328 (2020) 